Izvorni znanstveni rad - UDK - 159.923.3.072

159.942 .072

\title{
Struktura usredotočene svjesnosti i njezina povezanost s crtama ličnosti i emocionalnim reagiranjem
}

\author{
Asmir Gračanin \\ Odsjek za psihologiju, Filozofski fakultet Sveučilišta u Rijeci, Hrvatska \\ Vesna Gunjača \\ Centar za socijalnu skrb Imotski, Hrvatska \\ Mladenka Tkalčić, Igor Kardum, Igor Bajšanski \\ Odsjek za psihologiju, Filozofski fakultet Sveučilišta u Rijeci, Hrvatska \\ Benedikt Perak \\ Odsjek za kulturalne studije, Filozofski fakultet Sveučilišta u Rijeci, Hrvatska
}

\begin{abstract}
Sažetak
Cilj je provedenog istraživanja bio ispitati faktorsku strukturu Petofacetnog upitnika usredotočene svjesnosti (FFMQ, Baer i sur., 2006) na hrvatskom uzorku i utvrditi odnose usredotočene svjesnosti s relevantnim kriterijima. Uz ispitivanje originalne $\mathrm{i}$ alternativnih faktorskih struktura FFMQ-a ispitana je i njegova povezanost $\mathrm{s}$ iskustvom $\mathrm{u}$ meditaciji, neki aspekti konvergentno-divergentne valjanosti (povezanost $\mathrm{s}$ crtama ličnosti petofaktorskog modela) te prediktivna i inkrementalna valjanost u objašnjenju emocionalnog reagiranja na jednostavne podražaje. Ukupno 242 ispitanika iz populacije studenata i opće populacije od 18 do 68 godina popunilo je FFMQ, Petofaktorski inventar ličnosti (BFI, Benet-Martinez i John, 1998) i mjeru emocionalnog reagiranja operacionaliziranog kao evaluacija prezentiranih riječi na dimenzijama valencije i uzbuđenja, odnosno intenziteta afektivnog odgovora. Rezultati su pokazali da (1) iako sve facete FFMQ-a imaju primjerenu pouzdanost, najprikladnije faktorsko rješenje predstavlja četverofaktorski hijerarhijski model s jednim faktorom višeg reda, u kojem je izostavljen faktor opažanja, a moguće je koristiti i svih pet faktora, ali u tom slučaju bez podrazumijevanja faktora višeg reda; (2) uz kontrolu svih relevantnih varijabli postoje značajne razlike između praktikanata i nepraktikanata meditacije na svim facetama FFMQ-a osim facete opisivanja, kao i na ukupnom rezultatu FFMQ-a; (3) dobivene su niske do umjerene očekivane povezanosti faceta FFMQ-a s dimenzijama petofaktorskog modela; (4) povezanosti faceta FFMQ-a i emocionalnog reagiranja niske su, očekivano snažnije za negativne u odnosu na pozitivne podražaje i smjer im varira ovisno o vrsti facete i vrsti podražaja, pri čemu (5) faceta neprosuđivanja ima inkrementalnu valjanost povrh dimenzija petofaktorskog modela ličnosti jedino u predikciji percepcije intenziteta negativnih podražaja. Raspravljena su moguća objašnjenja i implikacije dobivenih rezultata.
\end{abstract}

Ključne riječi: Petofacetni upitnik usredotočene svjesnosti, validacija mjere, petofaktorski model ličnosti, emocionalno reagiranje

Asmir Gračanin, Odsjek za psihologiju, Filozofski fakultet Sveučilišta u Rijeci, Sveučilišna avenija 4, 51000 Rijeka, Hrvatska. E-pošta: agracanin@ffri.hr

Ovaj je članak nastao u okviru znanstvenih projekata "Ličnost, emocije i socijalni procesi kao odrednice zdravstvenih ishoda (13.04.1.2.01)" i "Biopsihosocijalni aspekti funkcionalnih crijevnih poremećaja" (13.04.1.3.17), koje financira Sveučilište u Rijeci. 


\section{Uvod}

Usredotočena svjesnost (US; engl. mindfulness) je koncept koji je u posljednjih desetak godina pobudio velik interes ne samo kliničkih psihologa već i znanstvenika u područjima psihologije ličnosti i kognitivne psihologije. US se najčešće definira kao povećano usmjeravanje pažnje na doživljaje koji se događaju u sadašnjem trenutku, i to na neprosuđujući ili prihvaćajući način (Brown i Ryan, 2003; Linehan, 1993). Opisi ovog stanja svijesti i metoda za njegovo postizanje potiču iz budističke filozofije, učenja starog dva i pol tisućljeća. U istočnjačkim se tradicijama US aktivno kultivira, primarno redovitim prakticiranjem meditacije. U budističkoj se tradiciji vjeruje da US dovodi do unapređenja i održavanja psihičkog zdravlja, točnije mira, staloženosti, uvida, mudrosti, suosjećanja i smanjivanja patnje (Didonna, 2009). Iz istog je razloga navedeni koncept postao predmetom znanstvenog interesa u psihologiji. Jednako tako, do danas su osmišljene i provedene razne kliničke intervencije temeljene na US-u. Njihovo trajanje varira od jednog dana do nekoliko mjeseci, a US se postiže ne samo meditacijom nego i provođenjem raznih drugih vježbi, poput terapije smanjenja stresa temeljeno na usredotočenoj svjesnosti (Mindfulness-Based Stress Reduction; MBSR; Kabat-Zinn, 1982; vidi također Keng, Smoski i Robins, 2011). Međutim, osim što se govori o skupu vještina koje se može uvježbati, većina autora smatra da se US može konceptualizirati i kao crtu ličnosti jer u općoj populaciji postoje interindividualne razlike u frekvenciji javljanja takvog stanja ili tendenciji ka usredotočeno svjesnom ponašanju i doživljavanju (npr. Baer, Smith i Allen, 2004; Baer, Smith, Hopkins, Krietemeyer i Toney, 2006; Brown i Ryan, 2003; Didonna, 2009).

Rezultati istraživanja provedenih na općoj i kliničkoj populaciji s višegodišnjim iskustvom redovitog prakticiranja meditacije idu u prilog važnosti crte US-a za psihičku dobrobit pojedinca. Zabilježena je i umjerena do visoka uspješnost kliničkih intervencija temeljenih na US-u u smanjenju simptoma široka raspona poremećaja, posebno anksioznosti, depresije i stresa te općenito u povećanju psihološke dobrobiti i kvalitete života (Keng, Smoski i Robins, 2011; Khoury i sur., 2013). Jedan od pristupa ispitivanju odnosa crte US-a i emocionalnog reagiranja počiva na dimenzionalnom modelu emocija, prema kojem su emocije, tj. emocionalne reakcije oblikovane duž triju osnovnih dimenzija: valencija (percipirani stupanj ugode odnosno neugode koju pojedini podražaj izaziva), uzbuđenje (percipirani intenzitet emocionalnog uzbuđenja koje pojedini podražaj izaziva) te dominacija (percipirani stupanj kontrole nad pojedinim podražajem) (Osgood, Suci i Tanenbaum, 1957). Valencija i uzbuđenje su međusobno nelinearno povezani, na način da je povećanje ugode i neugode praćeno povećanjem uzbuđenja, ali predstavljaju različite faktore i povezani su s odvojenim fiziološkim indikatorima (Lang, Greenwald, Bradley i Hamm, 1993). U ranijim se istraživanjima ispitivao odnos US-a s valencijom i uzbuđenjem pri reagiranju na negativne, neutralne i pozitivne podražaje. Tipične su mjere emocionalne reaktivnosti $\mathrm{u}$ takvim istraživanjima afektivna evaluacija neutralnih i averzivnih slika i/ili riječi, vrijeme reakcije u emocionalnom Stroopovu 
testu, osjetljivost na evaluativno uvjetovanje i sl. Ovakva su istraživanja pružila preliminarne dokaze da uvježbavanje US-a dovodi do smanjenja emocionalne reaktivnosti prema averzivnim podražajima, pa čak i javljanja pojačane aktivnosti lijevoga prefrontalnog korteksa u odnosu na desni, što se povezuje $\mathrm{s}$ većom pozitivnom emocionalnošću (Holzel i sur., 2011), te također do porasta pozitivnog afekta u odgovoru na pozitivne podražaje (Keng i sur., 2011). Međutim, treba napomenuti da ovakvi rezultati nisu dobiveni u svim studijama (Sauer i sur., 2011). Konačno, dosadašnja istraživanja upućuju na regulaciju pažnje, svjesnost tjelesnih senzacija, emocionalnu regulaciju i promjene u samopoimanju kao potencijalne mehanizme kojima US ostvaruje navedene pozitivne učinke. Ti mehanizmi djeluju $\mathrm{u}$ interakciji i usko su povezani te se mogu obuhvatiti pod zajedničkim nazivom unapređenja samoregulacije (Holzel i sur., 2011).

\section{Mjere usredotočene svjesnosti kao osobine}

Među instrumentima za mjerenje US-a prevladavaju upitnici samoprocjene. Svi su nastali unutar posljednjih petnaestak godina, a među najčešće korištenima su Skala usredotočeno svjesne pažnje i svjesnosti (MAAS; Brown i Ryan, 2003), Freiburški inventar usredotočene svjesnosti (FMI; Buccheld, Grossman i Walach, 2001), Kentucky inventar vještina usredotočene svjesnosti (KIMS; Baer i sur., 2004), Kognitivna i afektivna skala usredotočene svjesnosti (CAMS-R; Feldman, Hayes, Kumar, Greeson i Laurenceau, 2007), Southampton upitnik usredotočene svjesnosti (MQ; Chadwick i sur., 2008) i Petofacetni upitnik usredotočene svjesnosti (FFMQ; Baer i sur., 2006). Svi navedeni upitnici mjere tendenciju ka usredotočeno svjesnom ponašanju i doživljavanju u svakodnevnom životu, tj. mjere US kao crtu ličnosti. Međutim, oni pokazuju različite faktorske strukture, a ispitivanja njihove valjanosti pokazuju specifične obrasce povezanosti svake od skala s različitim kriterijskim varijablama. To je usko vezano uz činjenicu da različiti autori polaze od međusobno različitih konceptualizacija US-a, što sve skupa upućuje na to da postojeće skale ne zahvaćaju jednake aspekte US-a. S ciljem boljeg uvida u koncept US-a kao osobine te s ciljem razvoja instrumenta koji bi obuhvatio različite aspekte US-a, Baer i sur. (2006) konstruirali su Petofacetni upitnik usredotočene svjesnosti.

\section{Petofacetni upitnik usredotočene svjesnosti}

Petofacetni upitnik usredotočene svjesnosti nastao je na temelju faktorske analize čestica iz pet najčešće upotrebljavanih, ranije spomenutih upitnika US-a: MAAS, FMI, KIMS, CAMS i MQ. Sve čestice navedenih upitnika podvrgnute su eksploratornoj faktorskoj analizi. Petofaktorska je solucija objasnila 33\% varijance manifestnih varijabli, a ekstrahirani faktori su: 1. opažanje, 2. opisivanje, 3. djelovanje sa sviješću, 4. neprosuđivanje iskustva i 5. nereagiranje na unutarnje iskustvo. Sauer i sur. (2011) smatraju kako se pet navedenih faktora u osnovi odnose na dva faktora višeg reda: prisutnost (opažanje, opisivanje, djelovanje sa svijesti) i 
prihvaćanje (neprosuđivanje, nereagiranje), a isto shvaćanje prihvaćanja imaju i Baer i sur. (2006), iako navedene dvofaktorske strukture u pravilu nisu testirane.

Prva dimenzija, opažanje, označava tendenciju primjećivanja ili usmjeravanja pažnje na unutarnja i vanjska iskustva, što podrazumijeva misli, emocije i podražaje iz okoline (prizore, mirise, zvukove i sl.) te osjet vlastita tijela (primjer čestice: "Primjećujem kako hrana i piće utječu na moje misli, tjelesne doživljaje i emocije."). Druga, opisivanje, odnosi se na tendenciju opisivanja i označavanja unutarnjih iskustava riječima (npr. "Riječima dobro opisujem vlastite osjećaje."). Djelovanje sa sviješću podrazumijeva potpunu uključenost svjesnosti i pažnje u aktivnosti ili iskustva koja se trenutno odvijaju. Suprotnost je ovakvu ponašanju mentalna odsutnost ili mehaničko, automatsko obavljanje aktivnosti dok je pažnja usmjerena na nešto drugo (npr. "Nisam usredotočen na ono što radim jer sanjarim, brinem se ili mi nešto drugo odvlači pozornost."). Dimenzija neprosuđivanje unutarnjeg iskustva podrazumijeva neevaluativni stav prema vlastitim mislima i emocijama (npr. "Smatram kako su neke moje emocije loše ili neprimjerene i da ih ne bi trebao osjećati."). Naposljetku, nereagiranje na unutarnje iskustvo podrazumijeva tendenciju otpuštanja misli i emocija nasuprot prepuštanju istima (npr. "Kada mi na pamet padnu uznemirujuće misli ili slike, jednostavno ih primjetim i pustim da prođu.") (Baer i sur., 2006).

\section{Validacija FFMQ-a}

Svaka od pet subskala kao i jednofaktorski kompozit čestica FFMQ-a pokazuju umjerenu do visoku pouzdanost tipa unutarnje konzistencije u populaciji praktikanata meditacije, studenata i općoj populaciji različitih zapadnih kultura (npr. Baer i sur., 2006, 2008; de Bruin, Topper, Muskens, Bögels i Kamphuis, 2012; Giovannini i sur., 2014; Lilja i sur., 2011), dok u istočnim kulturama pojedine facete postižu nešto niže pouzdanosti (Deng, Liu, Rodriguez i Xia, 2011; Sugiura, Sato, Ito i Murakami, 2012). Nadalje, rezultati konfirmatornih faktorskih analiza pokazuju da svi faktori pripadaju nadređenom konstruktu US-a, osim opažanja, čija se pripadnost $\mathrm{u}$ velikom dijelu istraživanja pokazala ovisnom o iskustvu u meditaciji. Naime, $\mathrm{u}$ populacijama s iskustvom u meditaciji struktura US-a je petofaktorska, a u populaciji bez iskustva u meditaciji četverofaktorska (Baer i sur., 2006, 2008; Williams, Dalgleish, Karl i Kuyken, 2014). Takva je struktura potvrđena u različitima zapadnim kulturama (npr. de Bruin i sur., 2012; Giovannini i sur., 2014; Lilja i sur., 2011), a prva istraživanja US-a u kineskoj (Deng i sur., 2011) i japanskoj kulturi (Sugiura i sur., 2012) također je potvrđuju.

Interkorelacije faceta US-a kreću se, uz neke iznimke, u rasponu od niskih do umjerenih u populaciji japanskih studenata i različitim populacijama zapadnih kultura što, uz konfirmatornu faktorsku analizu kojom je utvrđena hijerarhijska struktura, pokazuje kako one predstavljaju različite ali povezane koncepte (Baer i sur., 2006, 2008; de Bruin i sur., 2012; Giovannini i sur., 2014; Lilja i sur., 2011; Sugiura i sur., 2012). Međutim, ispitivanja povezanosti s drugim konstruktima 
pokazala su kako je korisno i opravdano odvojeno mjeriti različite facete jer prediktivna valjanost US-a i visina korelacije s mnoštvom drugih konstrukata značajno variraju među različitim facetama (Baer i sur., 2006; 2008; de Bruin i sur., 2012; Giovannini i sur., 2014; Sugiura i sur., 2012).

\section{Odnos usredotočene svjesnosti s drugim psihološkim konstruktima}

Giluk (2009) je na dosadašnjim istraživanjima odnosa US-a i dimenzija ličnosti petofaktorskog modela provela metaanalizu kojom je dobivena povezanost US-a s neuroticizmom -.58, savjesnosti .44, ugodnosti .30, otvorenosti .20 te ekstraverzijom .15. Novija istraživanja koja kao mjeru US-a rabe FFMQ pokazuju slične rezultate (Latzman i Mausda, 2013). Ukratko, opažene korelacije između faceta i temeljnih dimenzija ličnosti potvrđuju konvergentno-divergentnu valjanost faceta FFMQ-a (Baer i sur., 2006; Barnhofer, Duggan i Griffith, 2011; Bowlin i Baer, 2012; de Bruin i sur., 2012; Sugiura i sur., 2012).

Pri ispitivanju prediktivne valjanosti faceta US-a istraživači su se usmjerili na opće i specifične psihologijske simptome te razne mjere dobrobiti u populacijama studenata, praktikanata meditacije i općoj populaciji. Dosadašnji nalazi idu u prilog zaključku kako djelovanje sa sviješću, neprosuđivanje i nereagiranje imaju dobru, opisivanje ograničenu, a opažanje nikakvu prediktivnu valjanost (Baer i sur., 2006, 2008; Cash i Whittingham, 2010; de Bruin i sur., 2012). Osim toga, čini se kako svaka od faceta ima ulogu u specifičnim ishodima iako postoje određena preklapanja. Istraživanja koja su ispitivala inkrementalnu valjanost US-a mjerene FFMQ-om također daju obećavajuće rezultate. Primjerice, US ima inkrementalnu valjanost povrh neuroticizma (Barnhofer i sur., 2011; Feltman, Robinson i Ode, 2009) i crte ličnosti samokontrole (Bowlin i Baer, 2012) u predviđanju različitih ishoda povezanih sa zdravljem. Ipak, potrebno je provesti još istraživanja, posebno $s$ dodatnim kriterijskim varijablama i sličnim konstruktima kao dodatnim prediktorima prije donošenja konačnog zaključka o njezinoj inkrementalnoj valjanosti. Osim toga, dosad nije ispitivana prediktivna, odnosno inkrementalna valjanost US-a u predikciji emocionalnog reagiranja na jednostavne podražaje povrh nekih drugih konstrukata koji ga određuju, kao što su npr. crte ličnosti petofaktorskog modela. S druge strane, nađena je snažna povezanost dimenzija petofaktorskog modela s emocionalnom reaktivnosti na neurobiološkoj razini (npr. Canli i sur., 2001) i nešto slabija na ponašajnoj (npr. Larsen i Ketelaar, 1991), na način da najjaču povezanost bilježe ekstraverzija (povezana $s$ reagiranjem na pozitivne podražaje) i neuroticizam (povezan s reagiranjem na negativne podražaje).

Cilj je ovog istraživanja bio utvrditi (1) faktorsku strukturu i metrijske karakteristike hrvatskog prijevoda FFMQ-a, (2) povezanost iskustva meditacije s rezultatima na tom upitniku, (3) povezanost između faceta US-a i osobina ličnosti petofaktorskog modela, (4) povezanost aspekata US-a i emocionalnog reagiranja na averzivne, neutralne i pozitivne podražaje koji se sastoje od normiranog skupa riječi 
(prediktivna valjanost) te (5) doprinos US-a u predviđanju emocionalnog reagiranja povrh osobina ličnosti petofaktorskog modela (inkrementalna valjanost). Hipoteze su derivirane u skladu s teorijama o mehanizmima US-a i prethodno opisanim empirijskim nalazima.

Iako naš uzorak sadrži određen broj pojedinaca s iskustvom u meditaciji, $u$ njemu uvelike prevladavaju nepraktikanti, zbog čega očekujemo replikaciju hijerarhijske četverofaktorske strukture FFMQ-a kakva je utvrđena i u ranijim istraživanjima na uzorcima nepraktikanata meditacije. Nadalje, pretpostavljamo kako će praktikanti meditacije postići značajno viši rezultat na generalnom faktoru kao i na facetama FFMQ-a u odnosu na nepraktikante meditacije. Očekujemo i replikaciju obrazaca povezanosti između US-a i osobina ličnosti petofaktorskog modela dobivenih u metaanalizi Giluk (2009). Nadalje, facete US-a bi trebale predviđati manje negativne reakcije prema averzivnim podražajima, što će se očitovati na mjerama procijenjenog intenziteta i valencije prvenstveno negativnih, normiranih podražaja. Također, predviđamo pozitivnije reakcije usredotočeno svjesnijih pojedinaca prema neutralnim i pozitivnim podražajima. S obzirom na dokaze o direktnom efektu potpuno uključene pažnje i usredotočeno svjesnog ponašanja na povećano uživanje i zadovoljstvo u određenoj aktivnosti (Brown i Ryan, 2007; prema Didonna, 2009; Csikszentmihalyi, 1990; Deci i Ryan, 1985; LeBel i Dube, 2001), može se očekivati da će i riječi koje odražavaju ili upućuju na neutralne i pozitivne aktivnosti, podražaje te emocije i mentalna stanja izazvati više ugode kod pojedinaca viših na dimenziji US-a. Naposljetku, predviđamo inkrementalnu valjanost US-a u predikciji navedenih reakcija povrh crta ličnosti petofaktorskog modela, među kojima najvažniju ulogu u emocionalnom reagiranju imaju neuroticizam i ekstraverzija. Opravdano je očekivati takve nalaze s obzirom na to da je US pokazao inkrementalnu valjanost povrh neuroticizma u predikciji drugih s emocijama povezanih ishoda (depresija i crta ljutnje) (Barnhofer i sur., 2011; Feltman i sur., 2009). Što se tiče ekstraverzije, ona i US dijele tek mali dio varijance, a $\mathrm{s}$ obzirom na opisanu ulogu US-a u pozitivnom emocionalnom reagiranju hipoteza je jasna.

\section{Metoda}

\section{Ispitanici i postupak}

U istraživanju je sudjelovalo 242 studenata različitih studija na Filozofskom fakultetu u Rijeci, odnosno dobrovoljaca regrutiranih od strane studenata psihologije (74.89\% žena; $M_{d o b}=22.00, S D=7.75$; stručna sprema: $67.1 \%$ SSS, $14.6 \%$ VŠS i $18.3 \%$ VSS). Od toga je 25 (10.3\%) ispitanika imalo iskustva u prakticiranju US-a (52\% žena; $M_{d o b}=36.33, S D=11.66 ; 28 \%$ SSS, $12 \%$ VŠS i $60 \%$ VSS), a njih 217 $(89.7 \%)$ bilo je bez takvog iskustva (74.14\% žena; $M_{d o b}=25.34, S D=10.51 ; 67.9 \%$ SSS, $15.8 \%$ VŠS i $18.3 \%$ VSS). Ispitivanje je provođeno u grupama od 5 do 30 
ispitanika, pri čemu su mjerni instrumenti primjenjivani redoslijedom kojim su prikazani u ovom radu.

\section{Instrumentarij}

Petofacetni upitnik usredotočene svjesnosti (FFMQ; Baer i sur., 2006) preveden je na način da su tri psihologa najprije prevela upitnik s engleskog na hrvatski jezik, a potom je profesor engleskoga jezika preveo upitnik s hrvatskog na engleski jezik. Nakon revidiranja uočenih razlika između prevedene i originalne verzije, uz konzultiranje s lingvistom, usuglašena je konačna hrvatska verzija. Upitnik se sastoji od 39 čestica (primjeri su navedeni u uvodnom dijelu rada) za koje ispitanik treba procijeniti u kojoj se mjeri tvrdnje odnose na njega koristeći se Likertovom skalom procjene od pet stupnjeva (od 1 - nikada do 5 - uvijek). Originalna struktura upitnika podrazumijeva pet faceta opisanih u uvodnom dijelu ovog rada. Svaka faceta sadrži osam čestica osim nereagiranja, koje sadrži sedam čestica.

U istraživanju je korišten Petofaktorski inventar ličnosti (BFI, Big Five Inventory; Benet-Martinez i John, 1998). Upitnik mjeri ekstraverziju, ugodnost, savjesnost, neuroticizam i otvorenost, a sastoji se od 44 čestice (npr. "Sebe vidim kao osobu koja je pričljiva.") za koje ispitanik treba procijeniti u kojoj se mjeri odnose na njega na Likertovoj skali procjene od pet stupnjeva - od 1 (uopće se ne slažem) do 5 (u potpunosti se slažem). Na hrvatskoj su populaciji ranije dobivene pouzdanosti tipa unutarnje konzistencije (Cronbach alpha) primjerene (Kardum, Gračanin i HudekKnežević, 2006). Na našem uzorku pouzdanosti iznose: .80 (ekstraverzija), .72 (ugodnost), .85 (savjesnost), .84 (neuroticizam) i .82 (otvorenost).

Kao mjera emocionalnog reagiranja korištena je afektivna evaluacija niza od 30 riječi koje se odnose na emocije, mentalna stanja te predmete ili pojave iz svakodnevnog života. Riječi su odabrane iz baze podataka ANEW (engl. Afective Norms for English Words) (Bradley i Lang, 1999), koja sadrži norme za 1040 riječi (imenice, pridjeve i glagole) na engleskom jeziku. Odabrane su i prevedene na hrvatski jezik samo imenice, a isključene su riječi $\mathrm{s}$ potencijalno nejasnim značenjem. Trideset odabranih riječi reprezentira cijeli opaženi raspon variranja duž triju osnovnih dimenzija procjene: valencija (percipirani stupanj ugode odnosno neugode koju pojedina riječ izaziva), uzbuđenje (percipirani intenzitet emocionalnog uzbuđenja koje pojedina riječ izaziva) i dominantnost (percipirani stupanj kontrole nad pojedinim podražajem) (Osgood i sur., 1957). U ovom su istraživanju riječi procjenjivane na dimenzijama valencije i uzbuđenja, dok je dimenzija dominantnosti izostavljena kao teorijski nerelevantna. Pri procjeni je korištena grafička skala od devet stupnjeva (Lang, 1980).

Valencija i intenzitet procijenjivani su za svaku od tri zasebne kategorije - za pozitivne, neutralne i negativne podražaje. $\mathrm{S}$ obzirom na opaženi minimum i maksimum u dimenziji valencije u bazi ANEW (Bradley i Lang, 1999) kreirana su tri razreda (predstavljaju trećine, tj. dijele raspon na tri jednaka dijela), u koja su 
potom odabrane riječi razvrstane prema svojoj srednjoj vrijednosti valencije opaženoj u ovom istraživanju: negativni podražaji (valencija od 1.97 do 3.70; 12 riječi; primjer: grobnica), neutralni podražaji (valencija od 3.71 do 6.25 ; 8 riječi; primjer: ugao), pozitivni podražaji (valencija od 6.26 do 8.34; 10 riječi; primjer: ljubav). Šest varijabli koje odgovaraju tim kategorijama sastavljeno je zasebnim agregiranjem odgovora (vezanih uz valenciju ili uz intenzitet) na negativne, neutralne i pozitivne skupine riječi. Odgovori su također agregirani i u dvije opće skale valencije i intenziteta podražaja (dakle, bez obzira na pripadnost jednoj od triju kategorija). Pouzdanosti (Cronbach alpha), aritmetičke sredine i standardne devijacije za svaku od navedenih skala prikazane su u Tablici 1. Više vrijednosti na dimenziji valencije podrazumijevaju pozitivnije procjene, odnosno, u slučaju valencije negativnih podražaja, manje negativne procjene. Kao što je vidljivo iz Tablice 1., opisane mjere pokazuju umjerenu do visoku pouzdanost.

Tablica 1. Aritmetičke sredine, standardne devijacije i pouzdanosti skala FFMQ-a i mjera emocionalnog reagiranja

\begin{tabular}{lcccc}
\hline Skale FFMQ-a & $\begin{array}{c}M(S D) \\
\text { Cijeli uzorak }\end{array}$ & $\begin{array}{c}M(S D) \\
\text { nepraktikanti }\end{array}$ & $\begin{array}{c}M(S D) \\
\text { praktikanti }\end{array}$ & $\begin{array}{c}\text { Cronbach } \\
\text { alpha } \\
\text { cijeli uzorak }\end{array}$ \\
\hline Opažanje & $3.42(0.61)$ & $3.37(0.60)$ & $3.79(0.51)$ & .72 \\
Opisivanje & $3.64(0.65)$ & $3.62(0.66)$ & $3.78(0.48)$ & .88 \\
Djelovanje sa sviješću & $3.28(0.60)$ & $3.24(0.60)$ & $3.61(0.48)$ & .82 \\
Neprosuđivanje & $3.24(0.75)$ & $3.18(0.72)$ & $3.74(0.82)$ & .87 \\
Nereagiranje & $3.12(0.55)$ & $3.07(0.54)$ & $3.58(0.47)$ & .71 \\
FFMQ4 & $3.32(0.42)$ & $3.28(0.40)$ & $3.68(0.35)$ & .87 \\
\hline Mjere emocionalnog & & & & \\
reagiranja & & & & .71 \\
Valencija podražaja & $5.16(0.48)$ & $5.15(0.49)$ & $5.25(0.47)$ & .88 \\
Intenzitet uzbuđenja & $4.52(1.11)$ & $4.56(1.07)$ & $4.18(1.35)$ & .84 \\
Valencija - negativni & $2.88(0.98)$ & $2.82(0.97)$ & $3.40(0.96)$ & .61 \\
Valencija - neutralni & $4.99(0.75)$ & $4.95(0.74)$ & $5.32(0.77)$ & .70 \\
Valencija - pozitivni & $7.62(0.74)$ & $7.67(0.69)$ & $7.14(0.92)$ & .88 \\
Intenzitet - negativni & $5.40(1.57)$ & $5.48(1.55)$ & $4.73(1.59)$ & .80 \\
Intenzitet - neutralni & $3.39(1.39)$ & $3.40(1.36)$ & $3.23(1.58)$ & .85 \\
Intenzitet - pozitivni & $4.76(1.60)$ & $4.78(1.61)$ & $4.58(1.51)$ & \\
\hline
\end{tabular}

Kratkim su upitnikom prikupljeni podaci o demografskim karakteristikama ispitanika - spolu, dobi i razini obrazovanja (srednja/viša/visoka). Ispitanici su također odgovorili na pitanje o prakticiranju meditacije: "Provodite li trenutno redovno (barem jednom mjesečno) ili ste nekada prije provodili meditaciju?" $(\mathrm{Da} / \mathrm{Ne})$. 


\section{Rezultati}

Faktorska struktura i pouzdanosti skala FFMQ-a

Da bismo provjerili faktorsku strukturu ovoga upitnika na matrici varijancikovarijanci između 39 čestica, provedene su tri konfirmatorne faktorske analize korištenjem statističkog programa LISREL 8.30 (Jöreskog i Sörbom, 1999). Kao polazna struktura za usporedbu najprije je testirana hipoteza o jednodimenzionalnosti ovoga upitnika, prema kojoj su sve čestice zasićene samo jednim faktorom. Nakon toga testirana je hipoteza o petofaktorskoj strukturi upitnika, koja uključuje faktore opažanja, opisivanja, djelovanja sa sviješću, neprosuđivanja i nereagiranja (Baer i su., 2006). U prvom su modelu s pet faktora dopuštene korelacije među njima, dok je drugim testirana hipoteza o njihovoj ortogonalnosti. Dobiveni indeksi pogodnosti za sva tri modela prikazani su u Tablici 2.

Tablica 2. Indeksi pogodnosti za tri testirane strukture (39 čestica)

\begin{tabular}{lccc}
\hline Indeksi pogodnosti & Jedan faktor & $\begin{array}{c}\text { Pet povezanih } \\
\text { faktora }\end{array}$ & $\begin{array}{c}\text { Pet ortogonalnih } \\
\text { faktora }\end{array}$ \\
\hline Hi-kvadrat; stupnjevi & $\chi^{2}=4506.05$ & $\chi^{2}=1500.31$ & $\chi^{2}=1662.30$ \\
slobode & $d f=702$ & $d f=692$ & $d f=702$ \\
& $p<.001$ & $p<.001$ & $p<.001$ \\
Normed Chi-square (NC) & 6.42 & 2.17 & 2.37 \\
Normed Fit Index (NFI) & 0.30 & 0.66 & 0.63 \\
Comparative Fit Index (CFI) & 0.36 & 0.79 & 0.75 \\
Goodness of Fit Index (GFI) & 0.51 & 0.76 & 0.74 \\
Root Mean Square Error of & 0.15 & 0.07 & 0.08 \\
$\begin{array}{l}\text { Approximation (RMSEA) } \\
\text { Root Mean Square Residual }\end{array}$ & 0.12 & & 0.08 \\
(RMR) & & & 0.11 \\
\hline
\end{tabular}

Općenito, o prikladnosti nekog testiranog modela govorimo onda kada je hikvadrat test neznačajan, NFI, CFI i GFI jednaki ili veći od 0.90, RMSEA jednak ili manji od 0.08, a RMR jednak ili manji od 0.10 (Hu i Bentler, 1999; Kline, 1998; Schermelleh-Engel, Moosbrugger i Müller, 2003). Hi-kvadrat test često je prekonzervativan i osjetljiv na veličinu uzorka, tako da je kod velikih uzoraka (većih od 200) rijetko neznačajan. Zbog toga se preporučuje da se on podijeli s brojem stupnjeva slobode (NC) te da se vrijednosti manje od tri mogu smatrati kao one koje govore u prilog testiranom modelu (Kline, 1998). Kao što se vidi iz Tablice 2., ni jedan indeks pogodnosti ne govori u prilog jednofaktorske strukture ovoga upitnika. Indeksi pogodnosti za petofaktorsku strukturu s međusobno povezanim faktorima znatno su bolji, pa vrijednosti NC-a, RMSEA-a i RMR-a govore o prikladnosti ove strukture, dok NFI, CFI i GFI ne dostižu gore navedene referentne vrijednosti. Kvantitativna usporedba hi-kvadrata kao indeksa pogodnosti također pokazuje da se 
petofaktorski model $\mathrm{s}$ međusobno povezanim faktorima znatno bolje poklapa $\mathrm{s}$ podacima nego jednofaktorski $\left(\Delta \chi^{2}=3005.74 ; \Delta d f=10 ; p<.001\right)$. Isto pokazuje i usporedba CFI-jeva indeksa pogodnosti $(\triangle \mathrm{CFI})$, koji iznosi 0.43 , a već vrijednosti od 0.01 govore o značajnom smanjenju prikladnosti modela (Hu i Bentler, 1998). Dobivene su niske do umjerene korelacije među faktorima (tj. faktorskim skorovima), koje se kreću od -.03 (opažanje i neprosuđivanje) do .47 (djelovanje sa sviješću i neprosuđivanje). Veličina i uzorak dobivenih korelacija ne govore u prilog mogućoj hijerarhijskoj strukturi koja bi na sljedećoj razini sadržavala jedan faktor, kao ni strukturi koja bi na sljedećoj razini sadržavala dva teorijski smislena faktora, od kojih bi jednim najviše bili zasićeni primarni faktori opažanja, opisivanja i djelovanja sa sviješću, a drugim neprosuđivanje i nereagiranje (Sauer i sur., 2011). Zbog toga u nastavku nije provedena konfirmatorna faktorska analiza kojom bi se provjeravala prikladnost navedenih struktura. Struktura s pet nepovezanih faktora također je znatno bolja od jednofaktorske, međutim, nešto lošija od one $\mathrm{s}$ pet povezanih faktora $\left(\Delta \chi^{2}=161.99 ; \Delta d f=10 ; p<.001 ; \Delta C F I=0.04\right)$. Kao i kod strukture s povezanim faktorima, pokazatelji koji govore o ukupnoj količini objašnjene varijance nešto su ispod preporučenih granica prihvatljivosti, dok su pokazatelji koji govore o rezidualnom varijabilitetu i razlici u strukturi kovarijanci populacije i one predviđene modelom prihvatljivi. Kao što se vidi iz Tablice 1., pouzdanosti unutarnje konzistencije (Cronbach alpha) za sve pojedinačne faktore i za generalni faktor su zadovoljavajuće i kreću se od .71 (nereagiranje) do .88 (opisivanje).

U skladu s nalazima Baer i sur. (2006) o prikladnosti četverofaktorske hijerarhijske strukture, dobivenim na uzorku iz opće populacije testirana je i struktura FFMQ-a bez osam čestica koje se odnose na faktor opažanja. Kao i u prethodnim slučajevima, konfirmatorne faktorske analize provedene su na matrici varijancikovarijanci, ali ovaj put na 31 umjesto na 39 čestica. Također je kao polazna hipoteza najprije testirana ona o jednodimenzionalnosti upitnika, a nakon toga su testirane dvije hipoteze o četverofaktorskoj strukturi: jedna $\mathrm{s}$ povezanim, a druga $\mathrm{s}$ ortogonalnim faktorima. Na kraju, testirana je i hipoteza o hijerarhijskoj strukturi, prema kojoj se na osnovi korelacija među četirima primarnim faktorima može izlučiti i jedan faktor višega reda. Dobiveni su indeksi pogodnosti za sva četiri modela prikazani u Tablici 3.

I u ovom slučaju nijedan indeks pogodnosti ne govori u prilog jednofaktorske strukture ovoga upitnika (Tablica 3.). Indeksi pogodnosti za četiri međusobno povezana faktora znatno su bolji, premda su NFI, CFI i GFI nešto ispod preporučenih granica prihvatljivosti. Kvantitativna usporedba također pokazuje da je ova struktura znatno prikladnija od jednofaktorske $\left(\Delta \chi^{2}=2227.74 ; \Delta d f=6 ; p<.001 ; \Delta \mathrm{CFI}=0.39\right)$. Struktura s četiri ortogonalna faktora također je znatno bolja od jednofaktorske, međutim, nešto lošija od one s četiri povezana faktora $\left(\Delta \chi^{2}=124.06 ; \Delta d f=6 ; p<.001\right.$; $\Delta \mathrm{CFI}=0.03)$. Kod strukture s četiri povezana faktora sve su korelacije značajne $\mathrm{i}$ pozitivne, i kreću se od .18 (neprocjenjivanje i nereagiranje) do .48 (djelovanje sa 
sviješću i neprosuđivanje). Dobivene korelacije govore u prilog postojanju jednog faktora višega reda, pa je testirana i hipoteza o hijerarhijskoj strukturi ovoga upitnika.

Tablica 3. Indeksi pogodnosti za četiri testirane strukture (31 čestica)

\begin{tabular}{lcccc}
\hline Indeksi pogodnosti & Jedan faktor & $\begin{array}{c}\text { Četiri } \\
\text { povezana } \\
\text { faktora }\end{array}$ & $\begin{array}{c}\text { Četiri } \\
\text { ortogonalna } \\
\text { faktora }\end{array}$ & $\begin{array}{c}\text { Hijerarhijska } \\
\text { struktura }\end{array}$ \\
\hline $\begin{array}{l}\chi^{2}=3373.49 \\
\text { Hi-kvadrat; stupnjevi }\end{array}$ & $\begin{array}{l}\chi^{2}=1145.75 \\
p<.001\end{array}$ & $\begin{array}{l}\chi^{2}=1269.81 \\
p<.001\end{array}$ & $\begin{array}{c}\chi^{2}=1147.99 \\
p<.001\end{array}$ & $\begin{array}{l}d f=430 \\
p<.001\end{array}$ \\
$\begin{array}{l}\text { Normed Chi-square } \\
\text { (NC) }\end{array}$ & 7.77 & 2.68 & 2.93 & 2.67 \\
$\begin{array}{l}\text { Normed Fit Index } \\
\text { (NFI) }\end{array}$ & 0.36 & 0.70 & 0.67 & 0.70 \\
$\begin{array}{l}\text { Comparative Fit } \\
\text { Index (CFI) }\end{array}$ & 0.41 & 0.80 & 0.77 & 0.80 \\
$\begin{array}{l}\text { Goodness of Fit } \\
\text { Index (GFI) }\end{array}$ & 0.53 & 0.77 & 0.75 & 0.76 \\
$\begin{array}{l}\text { Root Mean Square } \\
\begin{array}{l}\text { Error of } \\
\text { Approximation } \\
\text { (RMSEA) }\end{array}\end{array}$ & 0.17 & 0.08 & 0.09 & 0.08 \\
$\begin{array}{l}\text { Root Mean Square } \\
\text { Residual (RMR) }\end{array}$ & 0.12 & 0.08 & 0.12 & 0.08 \\
\hline
\end{tabular}

Model s faktorom višega reda jednako se dobro poklapa s podacima kao i model s četiri povezana faktora $\left(\Delta \chi^{2}=2.24 ; \Delta d f=2 ; p>.05\right)$, pa se može zaključiti da on dobro objašnjava korelacije između četiri primarna faktora. Svi su faktori prvoga reda značajno i zadovoljavajuće visoko zasićeni nadređenim faktorom: opisivanje .41, djelovanje sa sviješću .84 , neprocjenjivanje .56 i nereagiranje .42 . Pouzdanost unutarnje konzistencije (Cronbach alpha) ovoga generalnog faktora iznosi 87.

Zaključno, na temelju dobivenih indeksa pogodnosti i izravne kvantitativne usporedbe testiranih modela možemo zaključiti da je strukturu ovoga upitnika na hrvatskom jeziku najbolje konceptualizirati u terminima četiri ili pet primarnih, međusobno povezanih faktora, pri čemu je prednost četverofaktorske strukture $\mathrm{u}$ tome što ona može rezultirati jasnim generalnim faktorom višega reda koji dobro objašnjava korelacije među primarnim faktorima. U skladu s navedenim, načinjen je kompozit koji uključuje četiri faktora, te je u daljnjim analizama korišten kao sumarna mjera US-a (nadalje: $F F M Q 4$ ). U Tablici 4. prikazane su korelacije između svih pet primarnih faktora te njihove korelacije s $F F M Q 4-\mathrm{om}$. S obzirom na to da su na ukupnom uzorku utvrđene značajne povezanosti ukupnog rezultata odnosno pojedinih faceta FFMQ-a s dobi (npr. za $F F M Q 4$ : $r=.15$ ) i stručnom spremom (npr. nereagiranje: $r=.14$ ), te značajna spolna razlika (npr. nereagiranje: $t=2.89$; pri čemu muškarci postižu nešto viši rezultat), sve su daljnje analize provođene uz kontrolu 
navedenih varijabli. Prosječne vrijednosti, standardne devijacije i pouzdanosti (Cronbach alpha) pojedinih faceta i FFMQ4-a prikazani su u Tablici 1.

\section{Razlike između praktikanata i nepraktikanata}

Kako bi se utvrdilo razlikuju li se značajno praktikanti od nepraktikanata meditacije u US-u mjerenom FFMQ-om, provedena je jednosmjerna multivarijatna analiza kovarijance (MANCOVA). Praktikanti postižu nešto više rezultate na različitim aspektima US-a $\left[F(5,228)=4.73, p<.01 ; \eta p^{2=0.09] . ~ Z n a c ̌ a j n a ~ j e ~ r a z l i k a ~}\right.$

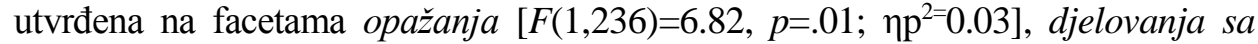
sviješć $\left[F(1,236)=4.24, p<.05 ; \eta p^{2=0.02]}\right.$, neprosuđivanja $[F(1,236)=9.87, p<.01$;

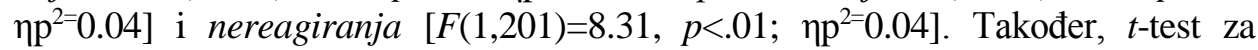
nezavisne uzorke pokazao je postojanje značajne razlike između dviju grupa na FFMQ4-u $[t(240)=4.80 ; p<.001]$. S obzirom na vrlo mali poduzorak praktikanata meditacije, odnosno na veliku razliku u veličini uzoraka praktikanata i nepraktikanata, ove rezulate treba sagledavati uz određeni oprez. Stoga smo razlike između dviju grupa testirali i neparametrijskim testom (Kruskal-Wallis), te su se one također pokazale značajnima.

\section{Odnos US-a i dimenzija ličnosti}

Parcijalne korelacije faceta i FFMQ4-a s crtama ličnosti petofaktorskog modela te rezultati regresijskih analiza kojima je ispitano u kojoj mjeri dimenzije petofaktorskog modela predviđaju facete i FFMQ4-a prikazani su u Tablici 4. Facete FFMQ-a nisko su do umjereno povezane s crtama ličnosti petofaktorskog modela. Od pozitivnih korelacija, opažanje pozitivno korelira samo s otvorenošću, a opisivanje s ekstraverzijom, savjesnošću i otvorenošću. Djelovanje sa sviješću pozitivno korelira sa svim dimenzijama petofaktorskog modela, osim s neuroticizmom. Neprosuđivanje pozitivno korelira s ekstraverzijom i savjesnošću, a nereagiranje s ugodnošću, savjesnošću i otvorenošću. Sve facete osim opažanja negativno su povezane s neuroticizmom. Konačno, FFMQ4 značajno korelira sa svim dimenzijama petofaktorskog modela ličnosti, sa svima pozitivno, osim s neuroticizmom. Regresijske analize dale su usporedive rezultate, s time da treba naglasiti da od faceta FFMQ-a, dimenzije ličnosti Petofaktorskog modela zajednički najbolje predviđaju djelovanje sa sviješću, te su posebno dobar prediktor FFMQ4-a. 
Gračanin, A., Gunjača, V., Tkalčić, M., Kardum, I., Bajšanski, I., Perak, B.:

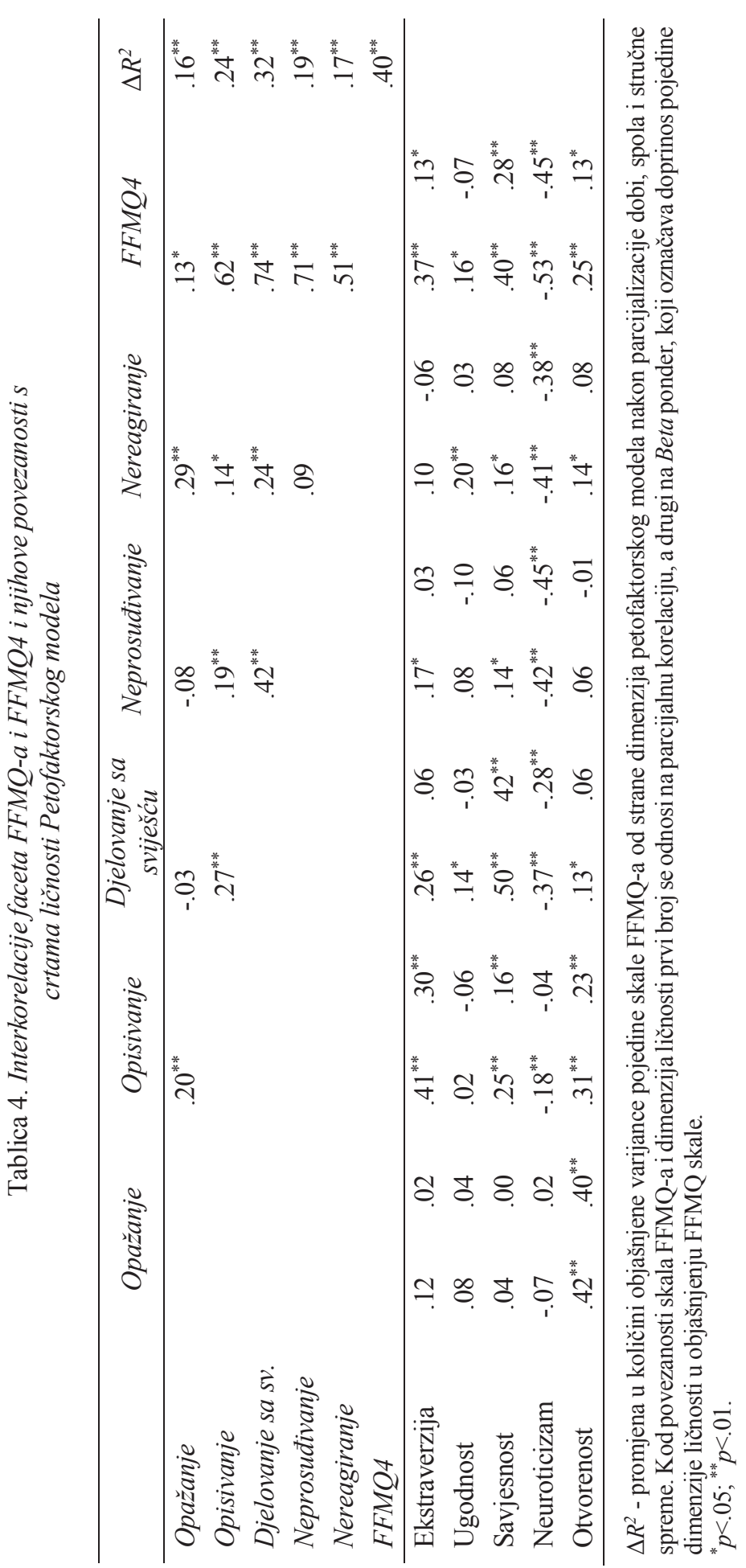




\section{Odnos US-a i afektivne evaluacije riječi}

Parcijalne korelacije svih faceta, FFMQ4 i dimenzija Petofaktorskog modela s procjenama valencije $\mathrm{i}$ intenziteta prikazane su u Tablici 5. Općenito, facete $\mathrm{i}$ FFMQ4 nisko su povezani s ovim varijablama, pri čemu je svaka od faceta povezana $\mathrm{s}$ barem jednim od osam mjerenih aspekata emocionalnog reagiranja. U skladu $\mathrm{s}$ hipotezama sve su postojeće korelacije faceta FFMQ-a s valencijom podražaja pozitivne, pri čemu su facete opažanja i nereagiranja povezane s agregiranom mjerom valencije, opisivanje s valencijom pozitivnih podražaja te nereagiranje $\mathrm{s}$ valencijom negativnih podražaja. Također očekivano, sve postojeće korelacije skala FFMQ-a s intenzitetom negativnih podražaja su negativne (odnosi se na neprosuđivanje i FFMQ4). Zanimljivo, opažanje je pozitivno, a djelovanje sa sviješć $u$, neprosuđivanje i FFMQ4 su negativno povezani s intenzitetom neutralnih podražaja. Usporedivo s time, agregirana mjera intenziteta negativno je povezana $\mathrm{s}$ neprosuđivanjem i FFMQ4. Konačno, ni jedna od skala FFMQ-a nije povezana s valencijom neutralnih podražaja i intenzitetom pozitivnih podražaja. Dimenzije Petofaktorskog modela nisko su povezane s mjerama afektivne evaluacije riječi.

S ciljem utvrđivanja prediktivne valjanosti faceta FFMQ-a u slučaju kada su sve odjednom uzete u obzir, provedene su hijerarhijske regresijske analize sa skalama FFMQ-a kao prediktorima i varijablama valencije i uzbuđenja kao kriterijima. Prvi su korak predstavljale kontrolne varijable: spol, dob, i razina obrazovanja, a drugi korak skale FFMQ-a. U nastavku su prikazani samo značajni prediktori (Tablica 6.). Facete upitnika FFMQ-a značajno objašnjavaju dodatnih 5\% varijance agregirane mjere intenziteta podražaja povrh kontrolnih varijabli. Značajni negativan prediktor intenziteta je neprosuđivanje. Navedeno je u skladu i sa sljedećim, očekivanim rezultatom koji pokazuje da facete upitnika FFMQ-a značajno objašnjavaju dodatnih $5 \%$ varijance intenziteta negativnih podražaja, pri čemu se neprosuđivanje također pokazuje kao jedini negativni prediktor. Konačno, facete upitnika FFMQ-a značajno objašnjavaju dodatnih $6 \%$ varijance intenziteta neutralnih podražaja, pri čemu se opažanje pokazuje kao jedini, pozitivni prediktor.

\section{Inkrementalna valjanost US-a u predikciji afektivne evaluacije riječi}

U svrhu utvrđivanja inkrementalne valjanosti skala FFMQ-a u predikciji procjene intenziteta podražaja povrh crta ličnosti petofaktorskog modela, provedene su tri hijerarhijske regresijske analize. Kao kriteriji su korištene samo one varijable za koje se u prethodnim analizama pokazalo da ih skale FFMQ-a značajno predviđaju. U prvi su korak uključene kontrolne varijable, u drugi dimenzije ličnosti, a u treći korak facete FFMQ-a (Tablica 6.). Dodatno, provedene su i tri hijerarhijske regresijske analize u kojima je umjesto faceta FFMQ-a kao prediktor uključen FFMQ4. U nastavku su detaljno prikazani samo značajni prediktori. Dimenzije ličnosti nisu se pokazale kao značajni prediktor za kriterij intenziteta podražaja $\left(\Delta R^{2}=.04 ; p>.05\right)$, ali sada ni facete FFMQ-a nisu značajno objašnjavale preostalu 
Gračanin, A., Gunjača, V., Tkalčić, M., Kardum, I., Bajšanski, I., Perak, B.:

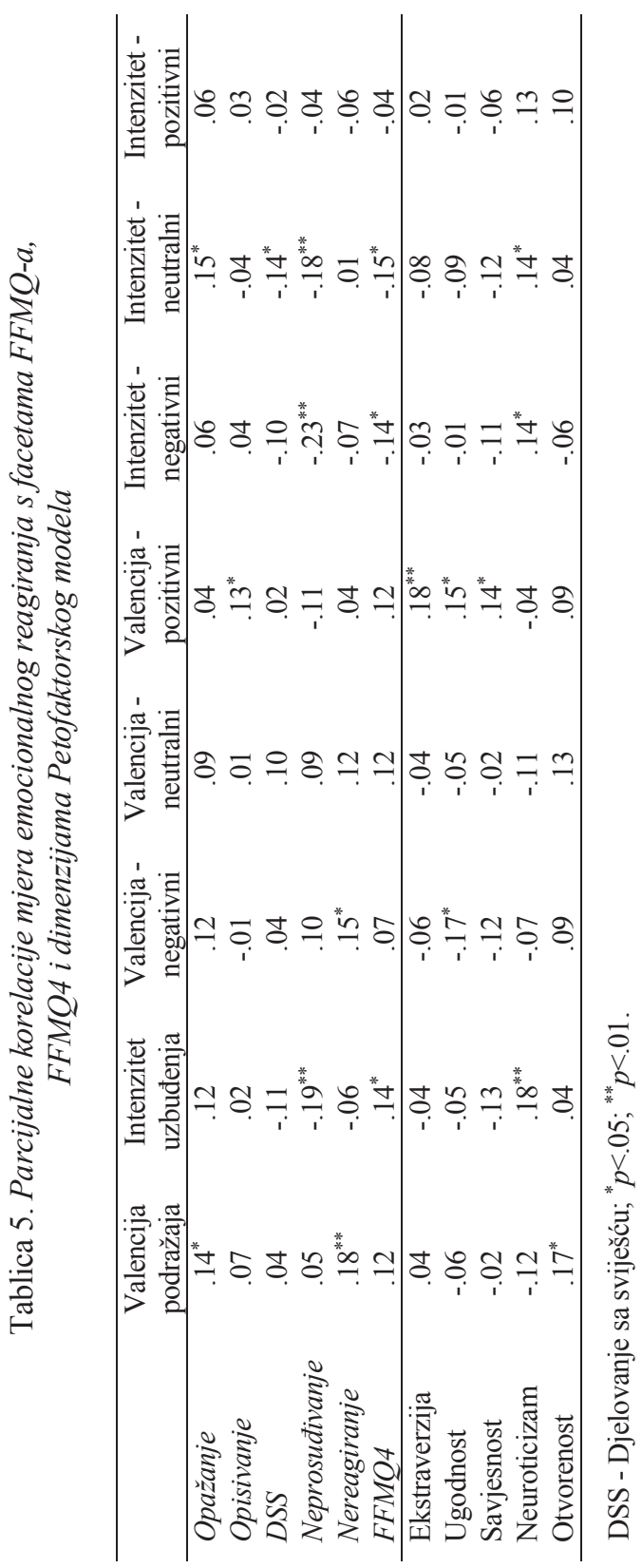


varijancu intenziteta podražaja $\left(\Delta R^{2}=0.03 ; p>.05\right)$. Jednako tako, dimenzije ličnosti nisu značajan prediktor intenziteta neutralnih podražaja $\left(\Delta R^{2}=0.03 ; p>.05\right)$, ali također izostaje i inkrementalna valjanost faceta FFMQ-a $\left(\Delta R^{2}=0.04 ; p>.05\right)$. Međutim, dok dimenzije ličnosti ne predviđaju značajno inenzitet negativnih podražaja, facete FFMQ-a ostaju značajan prediktor i povrh njih. Očekivano, neprosuđivanje pokazuje inkrementalnu valjanost u predikciji intenziteta negativnih podražaja. Nasuprot tome, $F F M Q 4$ ne predviđa ni jedan od tri kriterija koji se odnose na intenzitet podražaja povrh dimenzija petofaktorskog modela.

Tablica 6. Prediktivna i inkrementalna valjanost faceta FFMQ-a za kriterije intenziteta podražaja

\begin{tabular}{|c|c|c|c|}
\hline Kriterij / prediktori & Beta & $R^{2}$ & $\Delta R^{2}$ \\
\hline \multicolumn{4}{|l|}{ Intenzitet podražaja } \\
\hline 1. korak & & $.05^{* *}$ & \\
\hline Spol & $.18^{* * *}$ & & \\
\hline Dob & $.16^{*}$ & & \\
\hline 2. korak & & $.10^{* * *}$ & $.05^{*}$ \\
\hline Neprosuđivanje & $-.17^{*}$ & & \\
\hline \multicolumn{4}{|c|}{ Intenzitet negativnih podražaja } \\
\hline 1. korak & & $.18^{* * *}$ & \\
\hline Spol & $.38^{* *}$ & & \\
\hline Dob & $.18^{* *}$ & & \\
\hline 2. korak & & $.23^{* *}$ & $.05^{*}$ \\
\hline Neprosuđivanje & $-.22^{* *}$ & & \\
\hline \multicolumn{4}{|c|}{ Intenzitet neutralnih podražaja } \\
\hline 1. korak & & $.04^{*}$ & \\
\hline Dob & $.14^{*}$ & & \\
\hline 2. korak & & $.10^{* *}$ & $.06^{*}$ \\
\hline Opažanje & $.16^{*}$ & & \\
\hline \multicolumn{4}{|c|}{$\begin{array}{l}\text { Intenzitet negativnih podražaja } \\
\text { inkrementalna valjanost }\end{array}$} \\
\hline 1. korak & & $.17^{* * *}$ & \\
\hline Spol & $.37^{* *}$ & & \\
\hline Dob & $.18^{* *}$ & & \\
\hline 2. korak & & $.20^{* * *}$ & .02 \\
\hline 3. korak & & $.25^{* *}$ & $.05^{*}$ \\
\hline Neprosuđivanje & $-.21^{* *}$ & & \\
\hline
\end{tabular}

${ }^{*} p<.05 ;{ }^{* *} p<.01$; prikazani su samo značajni prediktori 


\section{Rasprava}

Na osnovi provedenih faktorskih analiza može se zaključiti da strukturu FFMQa u hrvatskom jeziku najbolje odražava četverofaktorska hijerarhijska struktura u kojoj su izostavljene čestice facete opažanja. Međutim, treba naglasiti da je petofaktorska struktura također prikladna, ali u tom slučaju ne možemo govoriti o općem fakoru US-a, već o pet nisko do umjereno povezanih faceta. Iz tog ćemo razloga u nastavku također komentirati i odnos opažanja s relevantnim kriterijima. Sve facete FFMQ-a pokazuju prihvatljivu do visoku pouzdanost, a korelacije četiri izdvojene facete s ukupnim rezultatom na upitniku (FFMQ4) umjerene su do visoke. Ovakvi su nalazi u skladu s rezultatima ranijih istraživanja (npr. Baer i sur., 2006, 2008; Williams i sur., 2014) u kojima je također utvrđeno da se na uzorcima ispitanika koji nemaju iskustva s meditativnom praksom faceta opažanja ne ponaša kao sastavni dio konstrukta US-a. O mogućim razlozima za drugačiju fakorsku strukturu FFMQ-a ovisno o meditativnoj praksi bit će riječi nešto kasnije. Uz to, treba napomenuti i da Sugiura i sur. (2012) izvještavaju o boljem podudaranju nehijerarhijskoga četverofaktorskog modela u odnosu na hijerarhijski u uzorku studenata iako je ta razlika mala, a isto za petofaktorski model opažaju i Bohlmeijer, ten Klooster, Fledderus, Veehof i Baer (2011) na uzorku depresivnih pacijenata. Drugim riječima, iako autori izvještavaju o replikaciji hijerarhijske strukture, čini se kako solucija u kojoj su facete neovisni konstrukti predstavlja jednako vjerojatnu mogućnost, što je tek djelomično u skladu s rezultatima našeg istraživanja. Takvi rezultati impliciraju da je US mjeren FFMQ-om relativno heterogen konstrukt te dodatno upućuju na korisnost uzimanja u obzir pojedinačnih faceta prije nego li ukupnog rezultata na ovom upitniku.

$\mathrm{U}$ svrhu su ispitivanja konstruktne valjanosti prvo ispitane razlike na facetama i FFMQ4-u između praktikanata i nepraktikanata meditacije. Ovdje treba napomenuti da je poduzorak praktikanata u našem istraživanju bio iznimno malen $(N=25)$. Unatoč tome, utvrđene razlike između dvaju poduzoraka teorijski su smislene i očekivane. Praktikanti meditacije izvještavaju o višem opažanju, djelovanju sa sviješću, neprosuđivanju i nereagiranju, te imaju povišen rezultat na općem faktoru US-a. Ovdje treba napomenuti da, iako smo kontrolirali efekte spola, dobi i razine obrazovanja, objašnjenje koje proizlazi iz naših nalaza ne implicira nužno da je bavljenje meditacijom korisno u kultiviranju US-a, već su opažene razlike među praktikantima i nepraktikantima potencijalno posljedica nekoga drugog čimbenika, što se može potkrijepiti i rezultatima istraživanja u kojima su korelacije faceta FFMQ-a s duljinom bavljenja meditacijom niske ili su dosezale visinu od maksimalno $r=.35$ (Baer i sur., 2008; Lykins i Baer, 2009). Kako su u istim istraživanjima dobiveni srednji i veliki efekti razlika između praktikanata $i$ nepraktikanata na facetama, očito je postojanje i drugih važnih aktivnosti za kultiviranje US-a koje je tek potrebno ispitati longitudinalnim istraživanjima. Međutim, bez obzira na mehanizam u podlozi ove povezanosti, dobiveni rezultati 
upućuju na diskriminativnu valjanost hrvatske verzije FFMQ-a, odnosno na mogućnost razlikovanja dviju teorijski relevantnih grupa na osnovi rezultata na FFMQ-u.

Uz kontrolu efekata dobi, spola i razine obrazovanja, generalni faktor US-a (FFMQ4) značajno i u očekivanom smjeru korelira sa svim dimenzijama petofaktorskog modela. Uočene su povezanosti u većini slučajeva niske do umjerene. Ovakvi su rezultati u skladu s hipotezama i repliciraju rezultate dobivene ranije spomenutom metaanalizom (Giluk, 2009). Zanimljivo je napomenuti da dobiveni rezultati u većoj mjeri odgovaraju rezultatima navedene metaanalize nego li brojnim pojedinačnim rezultatima prethodnih istraživanja u kojima su korištene različite mjere US-a (npr. Baer i sur., 2004; Hollis-Walker i Colosimo, 2011). Ovakav nalaz djelomično navodi na zaključak da se generalni faktor US-a koji proizlazi iz agregiranja rezultata na četiri facete FFMQ-a preklapa sa širokim spektrom mjera odnosno konceptualizacija US-a. FFMQ4 je, očekivano, u najvećoj mjeri (negativno) povezan s neuroticizmom. Govoreći o povezanostima na razini faceta, uočene su niske do umjerene negativne povezanosti neprosuđivanja, nereagiranja i djelovanja sa sviješću s ovom dimenzijom ličnosti. Vezanost ovih faceta s osobinom koju karakterizira negativna emocionalnost preklapa se i s njihovim povezanostima s reagiranjem na emocionalne podražaje o kojima govorimo u nastavku.

Facete FFMQ-a pokazuju nisku povezanost $\mathrm{s}$ različitim aspektima emocionalnog reagiranja. Neprosuđivanje je najbolji prediktor emocionalnog reagiranja, što se može interpretirati i u kontekstu ranijih istraživanja u kojima se ono također pokazalo jednim od najboljih i najkonzistentnijih prediktora s emocijama povezanih ishoda poput depresije, stresa i anksioznosti (npr. Cash i Whittingham, 2010). Dosadašnja istraživanja u američkoj i većini ostalih kultura upućuju na adaptivnost opisivanja i djelovanja sa sviješću (npr. Baer i sur., 2006, 2008; de Bruin i sur., 2012; Sugiura i sur., 2012; Williams i sur., 2014), što je u skladu s ovdje opaženim korelacijama s neuroticizmom (obje facete) i s valencijom pozitivnih podražaja (opisivanje). Zadnje navedeni rezultat također odgovara ranijim nalazima o pozitivnoj povezanosti aspekata US-a i reagiranja na pozitivne podražaje (Keng i sur., 2011). Međutim, iznenađuje odsustvo povezanosti djelovanja sa svijesti s reagiranjem na emocionalne podražaje (osim percepcije intenziteta neutralnih podražaja). Takvi su rezultati u suprotnosti s rezultatima ranijih istraživanja (Csikszentmihalyi, 1990; Deci i Ryan, 1985; LeBel i Dube, 2001) i hipotezom Browna i Ryana (2003) o povećanom zadovoljstvu i uživanju u aktivnosti, koji proizlaze iz potpune uključenosti pažnje. Konačno, od svih skala US-a, jedino neprosuđivanje ima inkrementalnu valjanost povrh petofaktorskog modela ličnosti u predikciji emocionalnog reagiranja. Ovakvi rezultati govore o djelomičnoj korisnosti faceta FFMQ-a i povrh temeljnih osobina ličnosti, te su u skladu s ranijim nalazima koji konzistentno upućuju na važnost ove facete u predikciji različitih emocionalnih ishoda (npr. Cash i Whittingham, 2010). 
Glede ograničenja i nedostataka ovog istraživanja prvenstveno treba istaknuti nedovoljan broj ispitanika s iskustvom meditacije. Iako ovakav omjer meditatora i nemeditatora barem približno odražava stanje $u$ ciljanoj populaciji, broj prvonavedenih ispitanika nije nam omogućio dodatno testiranje (pet)faktorske strukture FFMQ-a na rezultatima pojedinaca s iskustvom u meditaciji. Uz to, također zbog veličine poduzorka meditatora, rezultate usporedbe na skalama FFMQ-a među grupama, iako su relativno jasni i smisleni, treba ipak uzeti s dozom opreza. Nadalje, u budućim bi istraživanjima bilo korisno ispitati emocionalno reagiranje drukčijim metodama, poput mjerenja fizioloških odgovora, što bi omogućilo i ispitivanje hipoteze o pozitivnim učincima US-a na brži povratak organizma u početno stanje nakon emocionalnog reagiranja, što predstavlja znatno drugačiji aspekt emocionalnog funkcioniranja u usporedbi sa samoizvještavanjem o reakcijama na prezentirane riječi. Konačno, upitničko mjerenje US-a samo je po sebi velik izazov (u usporedbi $\mathrm{s}$ mjerenjem nekih drugih stabilnih obilježja pojedinca). Brojne manjkavosti, kao i prijedloge njihova ublažavanja, prevladavanja ili izbjegavanja opisuju Grossman i Van Dam (2011). Primjerice, samprocjene predstavljaju problem jer postoji mnogo dokaza da je nečija percepcija vlastita ponašanja često u neskladu s ponašanjem (npr. West i Brown, 1975; Wilson i Gilbert, 2003), a trenutno ne postoje objektivni ponašajni i biološki indikatori US-a koji bi mogli poslužiti kao standard prilikom provjere valjanosti upitnika samoprocjene. Nadalje, u istraživanju Christophera, Christophera i Charoensuk (2009) budistički su redovnici postigli značajno niže rezultate na facetama opažanja, opisivanja i neprosuđivanja KIMS upitnika u usporedbi s američkim studentima bez iskustva u meditaciji. To upućuje na velik problem valjanosti postojećih upitnika US-a. Kao rješenje ovog problema Grossman i Van Dam (2011) predlažu korištenje intervjua umjesto upitnika samoprocjene.

Drugi problem predstavlja diferencijalno funkcioniranje čestica (DIF) $\mathrm{u}$ upitniku FFMQ što čini usporedbu određenih grupa nemogućom. DIF se odnosi na različito razumijevanje čestica ili različito odgovaranje na čestice između različitih grupa koje imaju isti ukupni rezultat. Drugim riječima, grupna je pripadnost bolji prediktor odgovora na česticu nego ukupni rezultat na upitniku. Kod FFMQ-a je nađeno da praktikanti meditacije podjednako prihvaćaju (označavaju da se odnosi na njih) čestice koje reflektiraju US i odbacuju (označavaju da se ne odnosi na njih) one koje reflektiraju njezinu odsutnost, dok studenti više odbacuju čestice koje reflektiraju odsutnost nego što prihvaćaju one koje reflektiraju US (vidi: Grossman i Van Dam, 2011; Van Dam, Earlywine i Danoff-Burg, 2009). Treći problem koji Grossman i Van Dam (2011) ističu je problem obrnuto kodiranih čestica upitnika MAAS koje su u FFMQ-u sadržane u skali djelovanja sa sviješću. Prema njima, odsutnost jednog ekstrema/kraja određene crte ne implicira i snažnu prisutnost drugog ekstrema/kraja. Na primjer, odsutnost depresivnih simptoma ne znači nužno da je osoba sretna, kao što i odsutnost tjelesnog oštećenja ne sugerira dobru fizičku formu. Autori ne tvrde da obrnuto kodirane čestice ne mogu biti korisne, već da je njihovo uključivanje $u$ instrument složen proces i da je velik problem ako je cijela 
skala sastavljena od takvih čestica. Dakle, prema ovim idejama djelovanje sa sviješću je mjera opće nepažljivosti i na taj bi je se način trebalo preimenovati, odnosno tretirati. Četvrti je problem vezan uz teškoću procjene, tj. dosjećanja stanja nepažljivosti kod osoba niske metasvjesnosti. Rezultati istraživanja upućuju na zaključak kako je mentalna odsutnost ili nepažljivost (srodna sanjarenju) obično povezana s nedostatkom metasvjesnosti (Schooler, 2002) i kako ljudi procesiraju vrlo malo elemenata vanjske okoline dok su u takvim stanjima ostavljajući vrlo malo znakova za doziv (Smallwood, Beach, Schooler i Handy, 2008). Dakle, moguće je da djelovanje sa sviješću nije čak ni osobito točna mjera nepažljivosti. Sličnu opasku donose i Christopher, Woodrich i Tiernan (2014) koji su intervjuirali 14 zen-budista (svećenika i laika) u svrhu provjere kulturalne valjanosti upitnika FFMQ. Upozoravajući na subjektivnost čestica, oni ističu kako svjesnost vlastite mentalne odsutnosti i prosuđivanja zapravo može biti pokazatelj razvijenog US-a. Posljednji je problem vezan uz facetu opisivanja. Grossman i Van Dam (2011) smatraju da, iako se ponekad upotrebljava u meditaciji baziranoj na US-u, opisivanje služi tek kao tehnika održavanja svjesnosti na sadašnjem trenutku, a sama po sebi zapravo ne odražava stupanj US-a.

Rezultati istraživanja opisanog u ovom radu upućuju na relativno dobre metrijske karakteristike novonastale hrvatske verzije upitnika FFMQ, na njegovu konvergentno-divergentnu valjanost, te na korisnost uzimanja u obzir prvenstveno njegovih faceta, ali i ukupnog rezultata u predikciji teorijski relevantnih emocionalnih kriterija. Nadalje, u slučaju potrebe za korištenjem jedinstvene mjere US-a, faktor višeg reda ne bi trebao uključivati čestice iz skale opažanja. Buduća bi istraživanja svakako trebala testirati povezanost rezultata na FFMQ-u s mjerama emocionalnog reagiranja koje nisu temeljene na samoprocjeni, ali isto tako bi trebalo pokušati dodatno validirati ovaj upitnik kroz njegovo povezivanje s drugim (npr. ponašajnim/testnim) mjerama US-a.

\section{Zahvale}

Zahvaljujemo Tanji Babić na pomoći u prikupljanju podataka i Vladimiru Takšiću na korisnim savjetima u vezi s obradom podataka. 


\section{Literatura}

Baer, R.A., Smith, G.T. i Allen, K.B. (2004). Assessment of mindfulness by self-report: The Kentucky Inventory of Mindfulness Skills. Assessment, 11, 191-206.

Baer, R.A., Smith, G.T., Hopkins, J., Krietemeyer, J. i Toney, L. (2006). Using self-report assessment methods to explore facets of mindfulness. Assessment, 13, 27-45.

Baer, R.A., Smith, G.T., Lykins, E., Button, D., Krietemeyer, J., Sauer, S. i Walsh, E. (2008). Construct validity of the Five Facet Mindfulness Questionnaire in meditating and nonmeditating samples. Assessment, 15, 329-342.

Barnhofer, T., Duggan, D. i Griffith, J.W. (2011). Dispositional mindfulness moderates the relation between neuroticism and depressive symptoms. Personality and Individual Differences, 51, 958-962.

Benet-Martinez, V. i John, O.P. (1998). Los cincos grandes across cultures and ethnic groups: Multitrait multimethod analyses of the Big Five in Spanish and English. Journal of Personality and Social Psychology, 75, 729-750.

Bohlmeijer, E., ten Klooster, P.M., Fledderus, M., Veehof, M. i Baer, R. (2011). Psychometric properties of the Five Facet Mindfulness Questionnaire in depressed adults and development of a short form. Assessment, 18, 308-320.

Bowlin, S.L. i Baer, R.A. (2012). Relationships between mindfulness, self-control, and psychological functioning. Personality and Individual Differences, 52, 411-415.

Bradley, M.M. i Lang, P.J. (1999). Affective norms for English words (ANEW): Instruction manual and affective ratings. Technical Report C-1, The Center for Research in Psychophysiology, University of Florida.

Brown, K.W. i Ryan, R.M. (2003). The benefits of being present: Mindfulness and its role in psychological well-being. Journal of Personality and Social Psychology, 84, 822-848.

Buchheld, N., Grossman, P. i Walach, H. (2001). Measuring mindfulness in insight meditation (Vipassana) and meditation-based psychotherapy: The development of the Freiburg Mindfulness Inventory (FMI). Journal for Meditation and Meditation Research, 1, 11-34.

Canli, T., Zhao, Z., Desmond, J.E., Kang, E., Gross, J. i Gabrieli, J.D.E. (2001). An fMRI study of personality influences on brain reactivity to emotional stimuli. Behavioral Neuroscience, 115, 33-42.

Cash, M. i Whittingham, K. (2010). What facets of mindfulness contribute to psychological well-being and depressive, anxious, and stress-related symptomatology? Mindfulness, $1,177-182$.

Chadwick, P., Hember, M., Symes, J., Peters, E., Kuipers, E. i Dagnan, D. (2008). Responding mindfully to unpleasant thoughts and images: Reliability and validity of the Southampton Mindfulness Questionnaire (SMQ). British Journal of Clinical Psychology, 47, 451-455. 
Christopher, M.S., Christopher, V. i Charoensuk, S. (2009). Assessing "Western" mindfulness among Thai Theravāda Buddhist Monks. Mental Health, Religion, \& Culture, 12, 303314.

Christopher, M.S., Woodrich, L.E. i Tiernan, K.A. (2014). Using cognitive interviews to assess the cultural validity of state and trait measures of mindfulness among Zen Buddhists. Mindfulness, 5, 145-160.

Csikszentmihalyi, M. (1990). Flow: The psychology of optimal experience. New York: HarperCollins.

De Bruin, E.I., Topper, M., Muskens, J.G.A.M., Bögels, S.M. i Kamphuis, J.H. (2012). Psychometric properties of the Five facets Mindfulness Questionnaire (FFMQ) in a meditating and a non-meditating sample. Assessment, 19, 187-197.

Deci, E.L. i Ryan, R.M. (1985). Intrinsic motivation and selfdetermination in human behavior. New York: Plenum Press.

Deng, Y.Q., Liu, X.H., Rodriguez, M. i Xia, C.Y. (2011). The Five Facet Mindfulness Questionnaire: Psychometric properties of Chinese version. Mindfulness, 2, 123-128.

Didonna, F. (2009). Clinical handbook of mindfulness. New York: Springer.

Feldman, G., Hayes, A., Kumar, S., Greeson, J. i Laurenceau, J.-P. (2007). Mindfulness and emotion regulation: The development and initial validation of the Cognitive and Affective Mindfulness Scale-Revised (CAMS-R). Journal of Psychopathology and Behavioral Assessment, 29, 177-190.

Feltman, R., Robinson, D.B. i Ode, S. (2009). Mindfulness as a moderator of neuroticismoutcome relations: A self-regulation perspective. Journal of Research in Personality, 43, 953-961.

Giluk, T. (2009). Mindfulness, Big Five personality, and affect: A meta-analysis. Personality and Individual Differences, 47, 805-811.

Giovannini, C., Giromini, L., Bonalume, L., Tagini, A., Lang, M. i Amadei, G. (2014). The Italian Five Facet Mindfulness Questionnaire: A Contribution to its validity and reliability. Journal of Psychopathology and Behevioral Assessment, 36, 415-423.

Grossman, P. i Van Dam, N.T. (2011). Mindfulness, by any other name ...: Trials and tribulations of sati in western psychology and science. Contemporary Buddhism, 12, 219-239.

Hollis-Walker, L. i Colosimo, K. (2011). Mindfulness, self-compassion and happiness in nonmeditators: A theoretical and empirical examination. Personality and Individual Differences, 50, 222-227.

Holzel, B.K., Lazar, S.W., Gard, T., Schuman-Olivier, Z., Vago, D.R. i Ott, U. (2011). How does mindfulness meditation work? Proposing mechanisms of action from a conceptual and neural perspective. Perspectives on Psychological Science, 6, 537-559.

Hu, L. i Bentler, P. (1998). Fit indices in covariance structure modeling: Sensitivity to underparameterized model misspecification. Psychological Methods, 3, 424-453. 
Jöreskog, K.G. i Sörbom, D. (1999). LISREL 8 user's reference guide. Lincolnwood, IL: Scientific Software International.

Kabat-Zinn, J. (1982). An outpatient program in behavioral medicine for chronic pain patients based on the practice of mindfulness meditation: Theoretical considerations and preliminary results. General Hospital Psychiatry, 4, 33-47.

Kardum, I., Gračanin, A. i Hudek-Knežević, J. (2006). Odnos crta ličnosti i stilova privrženosti s različitim aspektima seksualnosti kod žena i muškaraca. Psihologijske teme, 15, 101-128.

Keng, S.L., Smoski, M.J. i Robins, C.J. (2011). Effects of mindfulness od psychological health: A review of empirical studies. Clinical Psychology Review, 31, 1041-1056.

Khoury, B., Lecomte, T., Fortin, G., Masse, M., Therien, P., Bouchard, V., Chapleau, M.-A., Paquin, K. i Hofmann, S.G. (2013). Mindfulness-based therapy: A comprehensive meta-analysis. Clinical Psychology Review, 33, 763-771.

Kline, R.B. (1998). Principles and practice of structural equations modeling. New York: Guilford.

Lang, P.J. (1980). Behavioral treatment and bio-behavioral assessment: Computer applications. U: J.B. Sidowski, J.H. Johnson i T.A. Williams (Ur.), Technology in mental health care delivery systems (str. 119-137). Norwood, NJ: Ablex Publishing.

Lang, P.L., Greenwald, M.K., Bradley, M.M. i Hamm, A.O. (1993). Looking at pictures: Affective, facial, visceral and bihevioral reactions. Psychophysiology, 30, 261-273.

Larsen, R.J. i Ketelaar, T. (1991). Personality and susceptibility to positive and negative emotional states. Journal of Personality and Social Psychology, 61, 132-140.

Latzman, R.D. i Masuda, A. (2013). Examining mindfulness and psychological inflexibility within the framework of Big Five personality. Personality and Individual Differences, $55,129-134$.

LeBel, J.L. i Dube', L. (2001). The impact of sensory knowledge and attentional focus on pleasure and on behavioral responses to hedonic stimuli. Paper presented at the 13th annual American Psychological Society Convention, Toronto, Ontario, Canada.

Lilja, L.J., Frodi-Lundgren, A., Johansson Hanse, J., Josefsson, T., Lundh, L.-G., Skold, C., Hansen, E. i Broberg, A.G. (2011). Five Facet Mindfulness Questionnaire - reliability and factor structure: A Swedish version. Cognitive Behaviour Therapy, 40, 291-303.

Linehan, M.M. (1993). Cognitive-behavioral treatment of borderline personality disorder. New York: Guilford.

Lykins, E.L.B. i Baer, R.A. (2009). Psychological functioning in a sample of long- term practitioners of mindfulness meditation. Journal of Cognitive Psychoterapy: An International Quarterly, 23, 226-241.

Osgood, C., Suci, G. i Tannenbaum, P. (1957). The measurement of meaning. Urbana, IL: University of Illinois. 
Sauer, S., Walach, H., Schmidt, S., Hinterberger, T., Horan, M. i Kohls, N. (2011). Explicit and implicit emotional behavior and mindfulness. Consciousness and Cognition, 20, 1558-1569.

Schermelleh-Engel, K., Moosbrugger, H. i Müller, H. (2003). Evaluating the fit of structural equation models: Test of significance and descriptive goodness-of-fit measures. Methods of Psychological Research Online, 8, 23-74.

Schooler, J.W. (2002). Re-representing consciousness: Dissociations between experience and meta-consciousness. Trends in Cognitive Sciences, 6, 339-344.

Smallwood, J., Beach, E., Schooler, J.W. i Handy, T.C. (2008). Going AWOL in the brain: Mind wandering reduces cortical analysis of external events. Journal of Cognitive Neuroscience, 20, 458-469.

Sugiura, Y., Sato, A., Ito, Y. i Murakami, H. (2012). Development and validation of the Japanese version of the Five Facet Mindfulness Questionnaire. Mindfulness, 3, 85-94.

Van Dam, N.T., Earlywine, M. i Danoff-Burg, S. (2009). Differential item function across meditators and non-meditators on the Five Facet Mindfulness Questionnaire. Personality and Individual Difference, 47, 516-521.

West, S.G. i Brown, T.J. (1975). Physical attractiveness, the severity of the emergency and helping: A field experiment and interpersonal simulation. Journal of Experimental Social Psychology, 11, 531-538.

Williams, M.J., Dalgleish, T., Karl, A. i Kuyken, W. (2014). Examining the factor structures of the Five Facet Mindfulness Questionnaire and the Self-Compassion Scale. Psychological Assessment, 26, 407-418.

Wilson, T.D. i Gilbert, D.T. (2003). Affective forecasting. U: M. Zanna (Ur.), Advances in experimental social psychology (str. 345-411). New York: Elsevier.

\title{
The Structure of Mindfulness and its Relationship with Personality Traits and Emotional Responding
}

\begin{abstract}
We explored factor structure of Five Facet Mindfulness Questionnaire (FFMQ, Baer et al., 2006) in a Croatian sample and its relationship with relevant criteria. In addition to testing of the original and alternative factor structures of FFMQ, we also tested its relationship with meditation experience, as well as some aspects of convergent-divergent validity (relationship with Five-factor model personality dimensions) and its predictive and incremental validity in explaining emotional responses to simple stimuli. In a sample of 244 participants (ages $18-$ 68 ) from a population of university students and general population, we administered FFMQ, Big Five Inventory (BFI, Benet-Martinez \& John, 1998), and a measure of emotional responding operationalized as evaluation of different words on valence and arousal/emotional intensity dimensions. The results showed that: 1. Although all FFMQ facets do have adequate reliability, it was a four-four factor hierarchical model, without facet Observe and with one
\end{abstract}


higher-order factor that represented the most acceptable factor solution. A solution with five factors was also acceptable, but without a corresponding higher-order factor; 2. After controlling for all potentially confounding variables, significant differences between individuals with and without meditation experience in all FFMQ facets except the Describe facet, as well as in FFMQ composite, were found; 3. Several low to moderate, expected correlations between FFMQ facets and Five-factor model personality dimensions were observed; 4. Correlations between FFMQ facets and emotional responding were low and, expectedly, larger for negative than for positive stimuli, with direction of correlation being different for different facets and types of stimuli; and 5. The Nonjudge facet showed incremental validity above the Five-factor model dimensions only when predicting the intensity of negative stimuli. Potential explanations and implications of such results were discussed.

Key words: Five Facet Mindfulness Questionnaire, measure validation, Five-factor model of personality, emotional responding

\section{La estructura de la conciencia plena y su conexión con los rasgos de personalidad y la reacción emocional}

\section{Resumen}

El objetivo de este trabajo fue examinar la estructura factorial del Cuestionario de cinco facetas de la conciencia plena (FFMQ, Baer y col., 2006) en la muestra croata y determinar la relación entre la conciencia plena y los criterios relevantes. Se han examinado las estructuras factoriales originales y alternativas de FFMQ, tanto como su conexión con experiencias en la meditación, algunos aspectos de la validez convergente-divergente (relacionada con los rasgos de personalidad de los cinco grandes) y la validez predicativa e incremental para explicar la reacción emocional a estimulaciones simples. Un total de 242 examinados a la edad entre 18 y 68 años (estudiantes y populación general) ha completado FFMQ, Inventario de los cinco grandes (BFI, Benet-Martinez y John, 1998) y la medida de reacción emocional hecha como evaluación de palabras presentadas en las dimensiones de valencia y excitación, o sea, intensidad de la respuesta afectiva. Los resultados han demostrado que 1) aunque todas las facetas de FFMQ tienen una fiabilidad adecuada, la resolución factorial más adecuada sería el modelo jerárquico de cuatro factores con un modelo del orden superior, en el que se omite Observación, pero se pueden utilizar también todos los cinco factores, sólo que en este caso sin un factor del orden superior; 2) si se controlan todas las variables relevantes, se notan diferencias significativas en todas las facetas de FFMQ, menos en la faceta de Descripción y en resultado total de FFMQ, entre los que practican la meditación y los que no lo hacen; 3) se han obtenido conexiones esperadas bajas y moderadas entre las facetas FFMQ y las dimensiones del modelo de los cinco grandes; 4) las conexiones entre las facetas FFMQ y la reacción emocional son bajas, más fuertes para las estimulaciones negativas en comparación con las positivas y su dirección varía dependiendo del tipo de faceta y del tipo de estimulación, en lo que 5) la faceta de la Falta de deliberación tiene una validez incremental más allá de las dimensiones del modelo de los cinco grandes sólo en la predicción 
de la percepción de la intensidad de estimulaciones negativas. Se discuten posibles explicaciones e implicaciones de resultados obtenidos.

Palabras claves: Cuestionario de cinco facetas de la conciencia plena, validación de la medida, modelo de los cinco grandes, reacción emocional

Primljeno: 24.08.2017. 